$1-1-2011$

\title{
How Law Schools Benefit When Librarians Publish, Teach and Hold Faculty Status
}

Carol A. Parker

University of New Mexico - School of Law

Follow this and additional works at: https://digitalrepository.unm.edu/law_facultyscholarship

Part of the Law Commons

\section{Recommended Citation}

Carol A. Parker, How Law Schools Benefit When Librarians Publish, Teach and Hold Faculty Status, Southwest Association of Law Libraries Annual Meeting (2011).

Available at: https://digitalrepository.unm.edu/law_facultyscholarship/200

This Article is brought to you for free and open access by the UNM School of Law at UNM Digital Repository. It has been accepted for inclusion in Faculty Scholarship by an authorized administrator of UNM Digital Repository. For more information, please contact amywinter@unm.edu, Isloane@salud.unm.edu,sarahrk@unm.edu.

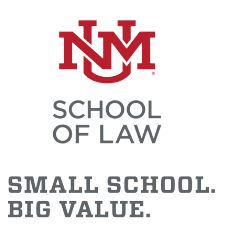

BIG VALUE. 


\title{
How Law Schools Benefit When Librarians Publish, Teach and Hold Faculty Status*
}

\author{
Carol A. Parker**
}

\begin{abstract}
Many non-director academic law librarians publish and teach legal research classes. Some hold faculty status as well. Law librarians have expertise in the development and delivery of legal research instruction methodologies and are developing a body of literature documenting their efforts to create and share a pedagogy of legal research instruction. Principles of shared faculty governance entitle library faculty to contribute to the development and delivery of a curriculum of legal research instruction. Encouraging law librarian participation in the shared governance of law schools should lead to increasing opportunities for the successful reform of legal education curricula with respect to legal research instruction.
\end{abstract}

\section{Table of Contents}

Introduction 1

How Law Schools Benefit From Librarian Scholarship ........................................................ 1

How Law Schools Benefit When Librarians Teach ............................................................. 5

How Law Schools Benefit When Librarians Hold Faculty Status and Contribute to Curriculum

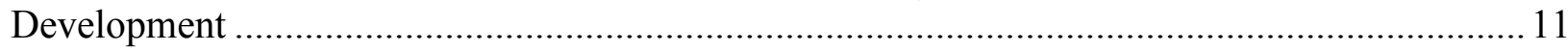

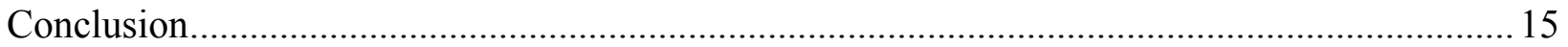

Appendix A -- Boulder Statement on Legal Research Education.......................................... 17

Appendix B -- Boulder Statement on Legal Research Education: Signature Pedagogy Statement

\footnotetext{
* This article was presented at the Conference on Legal Information: Scholarship and Teaching, held at the University of Colorado Law School on July 8-10, 2010, as part of its Boulder Summer Conference Series.

** Professor of Law and Associate Dean for Finance and Administration, University of New Mexico School of Law.
} 


\section{Introduction}

Significant benefits accrue to law schools when non-director law librarians with faculty status participate in the development of a pedagogy of legal research skills instruction through their scholarship, participate in the delivery of legal research skills instruction in the law school curriculum, and participate in the shared governance of their institutions. Law schools that embrace these concepts are more likely to correct problems associated with previous neglect of legal research skills instruction within the curricula of many law schools: namely, problems associated with graduating law students who are less than proficient at performing the critical lawyering skill of effective legal research.

\section{How Law Schools Benefit From Librarian Scholarship}

For some years now, law librarians have been working to develop a body of scholarship that focuses on the pedagogy of legal research skills instruction. Spurred on by the challenge to legal educators posed by the recent Carnegie Report, ${ }^{1}$ this work is garnering new attention and setting a new standard for law librarian scholarship. This emerging standard emphasizes application of principles of cognitive psychology that should form the basis for a pedagogy of legal research instruction, and identifies what is required of law students for them to become literate in principles and processes of legal information and research skills in the digital era. With such highly relevant areas of pedagogical inquiry ripe for development, and many

\footnotetext{
${ }^{1}$ William M. Sullivan et Al., Educating LaWyers: PreParation fOR the Profession OF LAW (2007) [hereinafter Carnegie Report]. The so-called Carnegie Report charges that law schools have overemphasized cognitive and doctrinal education at the expense of the practical and ethical-social education. For a summary of the report, see the Carnegie Foundation web site,

http://www.carnegiefoundation.org/files/elibrary/EducatingLawyers_summary.pdf (last visited October 6, 2009).

For a pithy but excellent historical overview of numerous curricular reform movements over the years, including the Carnegie Report, see Duncan Alford, The Development of the Skills Curriculum in Law Schools: Lessons for Directors of Academic Law Libraries, 28 Legal Reference Services Quarterly 301, 304-06 (2009).
} 
librarians rising to meet the challenge, law librarian scholarship is poised to have a real effect on legal education.

Kris Gilliland defined signature pedagogies in a recent piece focused on teaching legal research skills to first-year law students: "Signature pedagogies are characteristic sets of teaching and learning practices that are distinctive to professional education and include law's case-based method and medicine's clinical rounds.... Most importantly, signature pedagogies are engaging and require students to become active learners." ${ }^{2}$ Paul Callister has also garnered a reputation as a leader of this movement with recent work aimed at outlining a pedagogy for legal research instruction that reflects the work of Benjamin Bloom, an educational psychologist most known today for his taxonomy of learning domains. ${ }^{3}$

Such initiatives epitomize the ideal of making one's voice heard within the legal academy through one's scholarship. The scholarship associated with these efforts gives the authors' arguments weight they would not have were they merely argued orally or conveyed to internal audiences. Librarians increasingly are realizing that within the academy, if you want to influence or persuade, you must publish your argument and document it.

In the past law librarians perhaps tended too often to write for law librarian audiences, hiding their light under a bushel in the process. Duncan Alford has observed that "many law librarians have focused on bibliographic scholarship or scholarship dealing with the administration of law libraries. With a few exceptions, they have neither brought such topics

\footnotetext{
${ }^{2}$ Kris Gilliland, Motivational Perspective on First-year Legal Research Instruction, 28 Legal Reference Services Quarterly 63 (2009) (discussing 'signature pedagogies' and why they matter); see also, Alford, supra note 1 at 31112.

${ }^{3}$ See Paul D. Callister, Time to Blossom: An Inquiry into Bloom's Taxonomy as a Hierarchy and Means for Teaching Legal Research Skills, 102 LAW LIBR. J. 191 (2010).
} 
within the mainstream of legal education nor focused on scholarship related to their educational expertise of teaching legal research."4

Today law librarians increasingly recognize not only the need to support more mainstream scholarly topics and initiatives, but also the need to meet in workshop and conference settings to critique and encourage each other's scholarship. ${ }^{5}$ The 2009 formation of the Social Sciences Research Network, Legal Information and Technology e-Journal reflects the growing interest in providing law librarians with a forum for sharing their works in progress. $^{6}$

At the 2011 AALS Annual Meeting, law librarian authors (both directors and nondirectors) enjoyed an opportunity to present works in progress at the AALS Section on Law Libraries' program on Legal Research and Information Literacy: The Intersection of Intellectual and Practical Skills. The program's Call for Papers emphasized pedagogy and information literacy:

Presenters . . . will explore all aspects of legal research education and information literacy, including defining information literacy for legal professionals; the development of information literacy standards and outcome measurements; legal research instructional techniques, evaluation, and assessment; and the preparation of law students to become lifelong learners in the legal research field. ${ }^{7}$

\footnotetext{
${ }^{4}$ Alford, supra note 1 at 311-12. See also, Barbara Bintliff, The Roles and Status of the Academic Law Library Director, in INSIDE THE MINDS: THE LAW SCHOOL LIBRARIAN's ROLE AS AN EDUCATOR at 131 (Aspatore Books, 2008) ("Scholarship on topics related to law librarianship is critical to the law school program").

5 The American Association of Law Libraries has traditionally offered a variety of programming and initiatives to support librarian scholarship, including a Publishing Initiatives Caucus (www.aallnet.org/caucus/pic/index.htm). However, most of these initiatives focus on writing and publication tips rather than on providing substantive critiques of works in progress. Other regular programming at AALL meetings include the AALL LexisNexis Call for Papers Awards (www.aallnet.org/about/award_call_for_papers.asp) and a Writers' Workshop hosted by the AALL/LexisNexis Call for Papers Committee (see Writers' Workshop offered at AALL 2010 Annual Meeting, Strategic Librarian (Apr. 7, 2010), http://strategiclibrarian.com/2010/04/07/writers\%E2\%80\%99-workshop-offeredat-aall-2010-annual-meeting), both of which focus on how-to tips.

${ }^{6} \underline{\mathrm{http}: / / \text { www.ssrn.com/update/lsn/lsn_legal-info-tech.html. }}$

${ }^{7}$ Email on file with the author.
} 
Another notable initiative is the "Conference on Legal Information: Scholarship and Teaching." Organized by Barbara Bintliff in 2009 as part of the University of Colorado Law School's Boulder Summer Conference Series, attendees, including library directors and nondirector librarian scholars, presented scholarly works in progress and drafted a Boulder Statement on Legal Research Education describing the objectives of legal research instruction in terms consistent with the legal education reform framework expressed in the Carnegie Report (see Appendix A). A second Boulder conference in 2010 again provided attendees with an opportunity to present works in progress, advance the work of developing a legal research pedagogy, and strategize about ways to implement the Boulder Statement. The 2010 conference also led to the issuance of a Boulder Statement on Legal Research Education: Signature Pedagogy Statement (see Appendix B). ${ }^{8}$ In its short existence, in addition to producing the seminal Boulder Statements, the Conference on Legal Information has encouraged and assisted many law librarian scholars in getting their work published. ${ }^{9}$

Initiatives like the 2011 AALS Call for Papers and the Boulder Conferences raise expectations about what should constitute scholarship for law librarians and advance the profession of law librarianship. Teaching law faculties can help by recognizing the importance

\footnotetext{
${ }^{8}$ A third Boulder Conference is planned for 2011 to be held in Philadelphia, immediately preceding the AALL Annual Meeting. It will continue both the scholarly workshop on topics relating to legal information or legal research education, and deliberations on implementation strategies for the Boulder Statements. Barbara Bintliff email on file with the author.

${ }^{9}$ Several significant articles have come out of the Boulder conference workshops to date: Alford, supra note 1; Callister, supra note 3; Anne Klinefelter, First Amendment Limits on Library Collection Management, 102 LAW LIBR. J. 343 (2010); Susan Nevelow Mart, The Relevance of Results Generated by Human Indexing and Computer Algorithms: A Study of West's Headnotes and Key Numbers and LexisNexis's Headnotes and Topics, 102 LAW LIBR. J. 221 (2010); Sarah Valentine. Legal Research as a Fundamental Skill: A Lifeboat for Students and Law Schools, 39 U. BALT. L. REV. 173 (2010); Stephanie Davidson, Way Beyond Legal Research: Understanding the Research Habits of Legal Scholars, 102 LAW LIBR. J. 561 (2010), and Jootaek Lee, Legal Informatics: Metamorphosing Law Students into Legal Professionals Based on Empirical Evidence of Attorneys' Information Seeking Behaviors, accepted for publication in 39:1 INTL. J. LEGAL INFORMATION (2011).
} 
of this work and by inviting librarian scholars to present working papers at law school colloquia to provide invaluable feedback during the formative writing process.

\section{How Law Schools Benefit When Librarians Teach}

Many librarians now carry significant teaching loads and numerous law schools incorporate librarian-provided legal research instruction into the curriculum. However, librarian involvement in the legal research curriculum is not yet universal. Law schools that draw upon the expertise provided by law librarian teachers increase the likelihood that their law students will become proficient researchers by the time they graduate. Yet at too many law schools, legal research skills instruction is still treated as something less than a "fundamental lawyering skill," ${ }^{10}$ with adverse consequences to programs of legal instruction as a result. Despite the issuance of the MacCrate Report, this fundamental skill continues to be neglected in too many instances. $^{11}$

There is a growing realization that legal educators and the American Bar Association (ABA), Section of Legal Education and Admissions to the Bar, may have shortchanged law

\footnotetext{
${ }^{10}$ The ABA's MacCrate Report, published in 1992, designated legal research proficiency as a fundamental lawyering skill. American Bar Association, Section of Legal Education and Admissions to the Bar, Legal Education and Professional Development: An Educational Continuum: Report of the Task Force on Law Schools and the Profession: Narrowing the Gap (1992) (commonly referred to as "the MacCrate Report"). Some have asked whether legal research instruction is discounted at some schools because those most closely associated with legal research expertise - law librarians - are often discounted in law school hierarchies. See, e.g., Barbara Bintliff, Legal Research: MacCrate's 'Fundamental Lawyering Skill' Missing in Action, 28 Legal Ref. Services Quarterly 1 (2009).

${ }^{11}$ Id. at $\mathrm{n} .10$ ("I note that often there is a status hierarchy within law schools that can influence the perception of importance of a subject, including which classes are approved (or not) by the voting faculty. The statuses, analogized to Hindu castes, are, in order, 'tenured and tenure track faculty, deans, clinical faculty, law library directors, legal writing directors and faculty, and adjunct faculty. The untouchables, who are barely mentioned when we talk about what our institutions teach students, are, of course, the professional staff of law schools.' .... Law librarians may be faculty but often are professional staff; this could well influence the perceived importance of legal research, librarians' subject expertise." (citing Kent Syverud. The Caste System and Best Practices in Legal Education, 1 J. Ass'n. Legal Writing Directors 12, 13 (2002)). As if continuing this theme, the recent Carnegie Report that exhorts law teaching faculties to reform legal education to include more skills training barely mentions legal research skills. William Sullivan, et al., EdUCATING LAWYers: PrEPARATION FOR THE PRACTICE Of LAW (2007).
} 
students in the past by discounting the contribution law librarians can make as educators. ${ }^{12}$

Barbara Bintliff recently charged that the ABA Section on Legal Education has consistently

failed to enforce its accreditation standards with respect to legal research instruction:

If the ABA Section on Legal Education and its Accreditation Committee thinks legal research is important - and there is every reason to believe they do given accreditation Standard 302(a)(1) that "[a] law school shall require that each student receive substantial instruction in . . legal research . .."- - then legal research should be given much more attention than it has received in accreditation decisions, including during site visits and in written materials submitted as part of the law school's accreditation process. The lack of enforcement of Standard 302(a)(1) perpetuates the inattention paid to this fundamental skill by law schools across the country and undermines the entire accreditation system's purpose to serve the public interest. ${ }^{13}$ (cites omitted)

Despite this criticism, until relatively recently there has been inadequate discussion of how these concerns can be alleviated by significant librarian involvement in efforts to reform legal research skills instruction. Now as law schools come under more pressure to reform legal education by providing more opportunities for skills instruction, the need to tap the underutilized resource represented by law librarians to help meet these needs becomes more obvious. Librarian instructional roles should increase as law faculties see the logic of involving law librarians in this work. ${ }^{14}$ Also, more law librarians than ever now hold J.D. degrees which may lead to greater acceptance of law librarians in the classroom. $^{15}$

\footnotetext{
${ }^{12}$ Bintliff, supra note 10 at 1-2, 5-6.

${ }^{13} I d$. at 6.

${ }^{14}$ See Barbara Bintliff and Duncan Alford (co-editors). Special Issue: Teaching Legal Research 28(1-4) Legal Reference Services Quarterly (2009).

${ }^{15}$ This premise deserves a closer look, but doing so is outside the scope of this article. Providing anecdotal support is an informal survey conducted in 2009 by Jeffrey Woodmansee, Information Services Specialist at the University of Arkansas at Little Rock. Mr. Woodmansee posted an informal survey on legal research instruction models to the ALL-SIS listserv. Among other questions, he asked: "Do law librarians teach legal research at your school? If so,
} 
None of this means that librarians must be the exclusive teachers of legal research skills, but rather that at a minimum, law faculties-both doctrinal and skills teachers-should always involve librarians when developing programs of legal research instruction, and should also invite librarian contributions in the classroom.

Law librarians have a long tradition of providing instruction that can encompass bibliographic instruction, information literacy instruction, ${ }^{16}$ instruction that regularly takes place at the reference desk, and teaching formal classes within the law school curriculum. Historically, formal legal research instruction was nearly always taught by librarians. ${ }^{17}$ It has only been in the past several decades that law school faculties have bought into the belief that the process of legal research cannot be taught separately from the process of legal writing, and shifted responsibility for research instruction away from librarians to legal writing faculties. ${ }^{18}$ Duncan Alford observed that law librarians should be doing much more by way of teaching legal research, noting that "writing experts are infrequently also research experts, and the coupling of these fields is an unfortunate development for law students and practitioners

are they dual degree librarians?" Twenty-eight librarians replied with nearly all indicating that they teach legal research at their schools and that they are all dual degreed. In some instances, schools specifically prohibited nonJ.D. librarians from teaching in the law school, limiting them to tours, paralegals, and other campus groups. Email on file with the author.

${ }^{16}$ See Dennis Kim-Prieto, How Law Student Information Literacy (LSIL) Standards Address Deficits Identified by the MacCrate Report and the Carnegie Report, and What They Mean for Legal Research Education \& Training (working paper), available at http://ssrn.com/abstract=1678146. A number of recent developments with respect to legal information literacy have been reported at the Legal Informatics Blog, including the fact that the AALL has convened a Joint Committee on Articulating Law Student Information Literacy. Legal Informatics Blog $<$ http://legalinformatics.wordpress.com/2009/09/06/legal-research-instruction-recent-developments/> (last visited October 6, 2009). Also, as noted in the previous section, the 2011 AALS Annual Meeting included a Call for Papers on the topic of Legal Information Literacy. See supra note 7.

${ }^{17}$ Alford, supra note 1 at 306-07.

${ }^{18}$ See Helene S. Shapo, The Frontiers of Legal Writing: Challenges of Teaching Research, 78 Law Libr. J. 719, 725 (1986) ("The data thus indicates that, in most law schools, legal research is no longer taught by law librarians."); Bintliff, supra note 10 at 4 ("legal research can be taught effectively in a stand-alone course as in the context of a larger discussion"). 
alike." ${ }^{19}$ Given ongoing laments about poor legal research skills among recent law school graduates,${ }^{20}$ one would be hard-pressed to say that the experiment of giving responsibility for legal research instruction to legal writing faculty has yielded the hoped-for outcomes.

Legal education curricula in many schools devote too few credits to legal research skills instruction, and programs are too often developed sans input from law librarians. Teaching legal research has become more complex with the introduction of multiple formats and online resources. ${ }^{21}$ This is not to say that legal writing instructors cannot teach legal research skills in the digital era, provided they have the knowledge and experience about research methods that law librarians have. Rather, the question is whether law librarians could contribute to making the curriculum better, providing not only greater expertise in many cases, but also additional personnel to devote to the task.

It was probably unrealistic to ask legal writing instructors to be solely responsible for legal research instruction at their schools, given the Herculean task they already have of attempting to turn law students into legal writers. No doubt that is why some writing programs resort to using law students to teach research skills. ${ }^{22}$ Some law librarians report they would very much like to teach research skills at their schools, but they are not allowed to do so. It would be unfortunate if law schools relegated legal research instruction to law student teaching

\footnotetext{
${ }^{19}$ Alford, supra note 1 at 306.

${ }^{20}$ See Shapo, supra note 18 at 725 (reporting cause for concern for students' inadequate research skills as far back as 25 years ago, in light of the fact that fewer librarians are teaching research in favor of less-experienced instructors such as third-year law students or adjuncts).

${ }^{21}$ See Bintliff, supra note 10 at 2-4.

${ }^{22}$ Association of Legal Writing Directors, Legal Writing Institute, Report of the Annual Legal Writing Survey (2010) at ii (http://www.alwd.org/surveys/survey_results/2010 Survey_Results.pdf) ("at 25 schools teaching assistants and other students are responsible for teaching research;" this reflects $15 \%$ of survey respondents).
} 
assistants or adjunct faculty before looking to law librarians to help provide legal research instruction.

Frankly, many law teaching faculties are simply not in a position to develop the best possible programs of legal research instruction at their schools without librarian input. Law faculty members can lack the knowledge and expertise about research methodologies that law librarians have acquired by virtue of working with legal research materials on a daily basis.

Ironically, law librarians may be partly to blame for any research deficiencies on the part of law teaching faculties:

[L]aw librarians, through responsive services tailored to faculty needs, have so successfully insulated law faculty from the realities of today's research environment that the faculty are not making their curricular decisions based on actual knowledge of how research has changed since their years in law school and how it is currently conducted in law firms. For at least the last fifteen years, academic law libraries have emphasized "faculty services," dedicating personnel to providing expert research services to faculty on demand and assisting and supervising faculty research assistants to enable them to do the same. Many law faculty members no longer know how to research the law themselves and have lost sight of the importance of being able to research in both legal education and the daily practice of law. The end result is that law schools have decreased their emphasis on legal research instruction, neglecting this critical component of legal education. $^{23}$

The result is that there are too many law school graduates who are less than well equipped to master the essential skill of effective legal research in the digital era.

Fortunately, there is growing recognition of these problems and librarians are increasingly promoting librarian-taught courses in legal research skills in law schools. These courses consist of both stand-alone courses and courses that integrate both research and writing

${ }^{23}$ Bintliff, supra note 10 at 2-4 (citations omitted). 
skills instruction. These courses are growing in number in response to perceived deficiencies in current legal research instruction programs, especially in the first-year curriculum. ${ }^{24}$

The most consistent measure to date of librarian involvement in legal research instruction is the annual survey conducted by the Association of Legal Writing Directors Legal Writing Institute. In 2010, this survey enjoyed a record response rate of $96 \%$ of eligible schools, and over the past decade has enjoyed an average response rate of nearly $90 \%$. A review of the last ten years of answers to question 18 - one of only two survey questions devoted to research instruction - revealed little change in well-established patterns. At present, about $80 \%$ of research instruction is integrated with writing instruction, up from about $70 \%$ a decade ago. ${ }^{25}$ The other trend that can be seen from data of the past decade is a slight increase in the number of schools where librarians are involved in some way in teaching research, either exclusively or together with writing faculties. Currently, at about $60 \%$ of schools, law students enjoy the benefit of some form of law librarian involvement in their legal research instruction, either in

\footnotetext{
${ }^{24}$ Michael Chiorazzi and Shaun Esposito, Commentaries on Hicks' 'Teaching Legal Bibliography': With an Addendum by Robert Berring, 28 Leg. Ref. Serv. Q. 9, $20-21$ (2009), citing Nancy P. Johnson, Best Practices: What First-Year Law Students Should Learn in a Legal Research Class, 28 Leg. Ref. Serv. Q. 78 (2009) (example of stand-alone classes); Anita L. Morse, Research, Writing and Advocacy in the Law School Curriculum, 75 L. Lib. J. 232 (1982) (tracks trend to integrate research instruction with writing instruction); and Ann Hemmens, Advanced Legal Research Courses: A Survey of ABA-Accredited Law Schools, 94 L. Lib. J. 209 (2002) (describing trend to provide more advanced research instruction opportunities which first emerged in higher-ranked law schools).

${ }^{25}$ Respondents can select more than one answer, and percentages are rounded off. The 2010 survey had a response rate of $96 \%$ of eligible schools (191 respondents). The 2009 survey had a response rate of $84 \%$ of eligible schools (166 respondents). In 2010, in response to the question of whether research is taught separately from writing, nearly $82 \%$ indicated research is integrated with writing, and 34\% indicated research is taught separately. The 2009 responses were very similar, with $84 \%$ indicating research is integrated with writing and $32 \%$ indicating research is taught separately. In 2010, in response to the question of who teaches research at their schools, $29 \%$ indicated research skills are taught by librarians; at $40 \%$, it is taught by legal writing faculty; at $36 \%$, it is taught by both; and at $15 \%$, it is taught by upper-class law students or teaching assistants. In 2009, in response to the question of who teaches research at their schools, $28 \%$ indicated research skills are taught by librarians; at $44 \%$, it is taught by legal writing faculty; at $34 \%$, it is taught by both; and at $15 \%$, it is taught by upper-class law students or adjuncts.
}

ALWD Survey, supra note 22. 
their own classes or working together with writing instructors. Unfortunately, this means that at about $40 \%$ of law schools, librarians still have no involvement in legal research instruction. ${ }^{26}$

Given repeated complaints voiced by members of the bench and bar about the research skills of recent law school graduates, it is disheartening that many law schools still appear unwilling to question the wisdom of continuing these well-established patterns. At least the trend of librarian involvement in research instruction is moving in the right direction, but librarian-provided instruction needs to significantly increase in the future to benefit greater numbers of law students.

\section{How Law Schools Benefit When Librarians Hold Faculty Status and Contribute to Curriculum Development}

Given librarian expertise in teaching legal research skills, principles of shared faculty governance should entitle library faculty members to greater recognition of their expertise and increased opportunities for them to contribute to the development and delivery of a curriculum of legal research instruction within law schools. ${ }^{27}$ Moreover law faculties should recognize that faculty status for librarians is necessary if librarians are to fully contribute to the educational missions of law schools through the process of shared faculty governance. The institutional benefits that accrue from librarians holding faculty status accrue regardless of whether the

\footnotetext{
${ }^{26} I d$. (emphasis added).
}

${ }^{27}$ While teaching legal research skills and publishing scholarship related to development of a pedagogy of legal research instruction are not the only contributions librarians make to the educational mission of law schools, these contributions tend to lead to greater acceptance of librarians holding faculty status because the work is familiar to law teaching faculties. 
librarians hold faculty status as members of the law faculty, a university library faculty, or a separately created law library faculty. ${ }^{28}$

Faculty status for librarians . . . expands librarian roles, making them more aware of, responsible for, and involved in the overall educational process, and raises the stature of librarians in the eyes of the teaching faculty. . . . As faculty members, librarians are hired through rigorous processes similar to those undertaken to recruit teaching faculties. Librarians with faculty status participate in campus governance and have comparable criteria for retention, promotion in rank, and tenure. . . . Additionally, law schools, universities, and the profession of law librarianship as a whole benefit from the institutional and professional service that librarians with faculty status typically contribute, often as requirements for attaining tenure. (footnotes omitted) ${ }^{29}$

${ }^{28}$ Non-director law librarians who hold faculty status rarely, if ever, do so as members of teaching law faculties. Non-director law librarians typically hold faculty status either as members of small, separate law librarian faculties created within law schools, or as members of university-wide librarian faculties. This is in contrast with the status of law library directors who typically are members of teaching law faculties. Carol A. Parker, The Need for Faculty Status and Uniform Tenure Requirements for Law Librarians 103 L. Libr. J. (2011).

Perhaps unwisely, previous articles that attempted to make the case for non-director law librarians holding faculty status have emphasized benefits that accrue to the individual (status, job security, higher pay, etc.) rather than emphasizing benefits that accrue to the institution when librarians teach and publish as faculty members. In a few instances where authors seek to describe possible institutional benefits attributed to non-director librarians holding faculty status, they have pointed to a positive association with recruitment of superior candidates for librarian positions. See, e.g., Thomas G. English, Administrator's Views of Library Personnel Status, 45(3) College \& Research Libraries 189, 191, 194-95 (1984). Also, a study of general collection academic librarians revealed a link between the quality of the institution and librarians holding faculty and tenured status. Richard W. Meyer, $A$ Measure of the Impact of Tenure, College and Research Libraries at 110 (March 1999). However, there is no corollary study available with respect to law librarians. Rarely do authors seek to describe institutional benefits associated with non-director librarian contributions through scholarship and teaching. Much more likely are arguments that there is essentially no institutional benefit - and possibly even an institutional detriment - if librarians hold faculty status or have tenure opportunities. See Brian Huddleston, Types of Employment Status for Academic Librarians, in BEYOND THE BOOKS: PEOPLE, POLITICS, AND LIBRARIANSHIP, Leslie A. Lee, Ed. (William S. Hein \& Co., Inc., Buffalo, New York, 2007) at 43-44; and Thomas G. English, Administrator's Views of Library Personnel Status, 45(3) College \& Research Libraries 189, 195 (1984). Literature discussing a positive role of librarians in the educational mission of law schools often focuses on librarians' work supporting the law teaching faculty, as opposed to recognizing them as potential teachers and scholars in their own right, in addition to the role they play as librarians. One partial exception is an article based on a 1988 speech by John Attanasio, then a professor at Notre Dame, and now Dean at Southern Methodist's Dedman School of Law. At a workshop for law librarians and deans at the Annual Meeting of the Association of American Law Schools, Dean Attanasio did an excellent job of describing the institutional benefits of librarians teaching legal research, both formally and informally; however, he fell a bit short of the mark with respect to the institutional benefits of librarians' scholarship. He focused on the perceived negatives associated with librarians working on their own scholarship,as it would introduce "tension with what many envision to be the primary role of research librarians, that is, performing research for full-time teaching faculty" rather than working on their own scholarship. In any case, there was no mention of librarians potentially crafting a pedagogy of legal research instruction through their scholarship - not surprising since this has only recently gotten traction among law librarians, much less among law teaching faculty. See John B. Attanasio, Commentary: The Research Librarian in the Educational Mission of the Law School, 81 Law Libr. J. 143, 146-47 (1989).

${ }^{29}$ Parker, supra note 28 at 
Approximately one-quarter of law school librarians currently hold faculty status, either as members of small law library faculties or as members of university library faculties; but more deserve this recognition. ${ }^{30}$ Legal education would benefit from having more law librarians who hold faculty status partnering with law faculties to develop and implement legal research curricula. In light of ongoing efforts within law schools to incorporate additional skills training into legal education curricula, involvement of law librarians in the process of reforming legal research skills instruction is essential if these initiatives are to succeed.

According to the American Association of University Professors (AAUP), shared governance is "one of the key tenets of quality higher education" and "refers to governance of higher education institutions in which responsibility is shared by faculty, administrators, and trustees." 31 Faculty should "have primary responsibility for such fundamental areas as curriculum, subject matter and methods of instruction, research, faculty status, and those aspects of student life which relate to the educational process . ..."32 Fully implemented with respect to library faculty members, principles of shared governance clearly give them the right to have a say in determining the library mission, values, direction, and programming. ${ }^{33}$ However,

\footnotetext{
${ }^{30}$ Huddleston, supra note 28 at 46. See also, Katherine E. Malmquist, Academic Law Librarians Today: Survey of Salary and Position Information. 85 Law Libr. J. 135, 141, 148 (1993) (respondents to a 1991 survey indicated the number of non-director law librarians with faculty rank had decreased somewhat to about one-quarter of the respondents).

${ }^{31}$ AAUP, Informal Glossary of AAUP Terms and Abbreviations

$<$ http://www.aaup.org/AAUP/about/mission/glossary.htm> (last visited August 3, 2009).

${ }^{32} I d$.

${ }^{33}$ Association of College and Research Libraries Joint Statement on Faculty Status of College and University

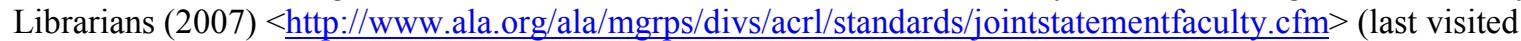
October 16, 2009) ("[L]ibrarians should also participate in the development of the institution's mission, curriculum, and governance. Librarians should participate in the development of policies and procedures for their library including the hiring, review, retention, and continuing appointment of their peers.”). See also, Rodney M. Hersberger, The Challenges of Leading and Managing Faculty Status Librarians, 14 (6) J. Acad. Librarianship 361, 363-65 (1989).
} 
principles of shared governance can also be interpreted to provide for law librarian participation in the development of the law school's curriculum with respect to librarians' area of expertiselegal research skills instruction. It is only fair that if librarians are going to be called upon in ever-increasing numbers to teach legal research in law school classes, then they should have the ability to contribute to the development of the curriculum associated with these classes.

Many law librarians hold advanced degrees in a discipline of study emphasizing research methodology (information science) in addition to holding law degrees. Law librarians are actively working to develop a pedagogy of legal research instruction that will inform curricular decisions in law schools as law teaching faculties move forward with implementing curricular reforms to provide more skills instruction for law students. Law librarians have extensive expertise with respect to teaching the process of legal research and can serve as catalysts of robust programs of legal research instruction. ${ }^{34}$ Librarians are thus well placed to contribute to the shared governance of law schools with respect to the development of legal research curricula and are uniquely placed to claim expertise as instructors of legal research. No other members of the legal academy are as well qualified as law librarians to make this claim. ${ }^{35}$

It is well documented that law librarians who work at university law schools are much more likely to hold faculty status, and thus be recognized as partners in the development of legal education curricula, than are librarians who work at stand-alone schools. ${ }^{36}$ The ABA Section of Legal Education and Admissions to the Bar should work to expand acceptance of faculty status for all law librarians, regardless of whether or not their employer is affiliated with a university.

\footnotetext{
${ }^{34}$ Alford, supra note 1 at 303-04.

${ }^{35}$ See, e.g., Mary Rumsey, The Skills They Need: International and Foreign Legal Research. 28 Leg. Ref. Serv. Q. 133, 144 (2009) ("Generally, experts agreed that librarians should teach legal research.").

${ }^{36}$ This likely reflects a broader acceptance within universities of librarians having opportunities to hold faculty status. Parker, supra note 28 at
} 
The ABA Section of Legal Education and Admissions to the Bar accreditation standards for law libraries currently state that library directors should be law faculty members. With respect to non-director academic law librarians, however, the ABA standards are silent as to status or rank and mention only that law librarians should be "competent.",37

It is doubtful that the current ABA standards could be interpreted as recognizing that curricular contributions can and should come from non-director law librarians in addition to law teaching faculties. The Section of Legal Education and Admissions to the Bar does at least recognize that some non-director law librarians currently hold faculty status. In its annual questionnaire, the Section currently counts librarians who hold faculty status or teach together with other law teaching faculty. Full-time librarians who do not teach or hold faculty status are counted in the library staff section. ${ }^{38}$ The ABA standards should be revised to encourage law schools to provide all academic law librarians with some form of faculty status, either as members of small law library faculties or as members of university library faculties, and to encourage librarians to contribute to legal educational policies with respect to legal research instruction.

\section{Conclusion}

The approach many law schools have taken for the past several decades for delivering legal research skills instruction has been less than ideal, given that effective legal research is a

\footnotetext{
${ }^{37}$ Section of Legal Education and Admissions to the Bar, American Bar Association, ABA STANDARDS FOR APPROVAL OF LAW SCHOOLS (2009-2010), § $604<$ http://www.abanet.org/legaled/standards/standards.html $>$ (last visited September 30, 2009).

${ }^{38}$ Section of Legal Education and Admissions to the Bar, American Bar Association, 2009-10 Annual Questionnaire, Part 5, a. ("Full-time employees who teach or hold faculty rank ... including administrators holding a decanal or director rank and librarians")

$<$ http://www.abanet.org/legaled/questionnaire/questionnairedocuments.html $>$ (last visited October 20, 2009).
} 
fundamental lawyering and legal skill and that legal educators continue to hear complaints from the bench and bar about law student research skills. The way forward for law faculties interested in improving the curriculum of legal research skills instruction is greater law librarian involvement in all aspects of curriculum development and delivery. Librarians represent an important and significant force for innovation in this area and represent untapped manpower that can help reverse neglect of this fundamental skill where it exists. Recognizing that non-director law librarians should have faculty status ultimately may be a key component to successful reform of legal research instructional curricula. 


\section{Appendix A -- Boulder Statement on Legal Research Education}

\section{Introduction}

The Conference on Legal Information: Scholarship and Teaching was attended by legal research professionals who gathered at the University of Colorado Law School in Boulder, Colorado on June 21-22, 2009, to discuss legal information scholarship and instruction. The following Boulder Statement on Legal Research Education was developed at that Conference and reflects the consensus of the conference participants on the theoretical foundation of a signature pedagogy for legal research education.

The Statement is based on the model proposed by the Carnegie Foundation's EDUCATING LAWYERS: PREPARATION FOR THE PROFESSION OF LAW (2007). Generally referred to as the "Carnegie Report," EDUCATING LAWYERS calls for a systemic revision of legal education. In particular, the Report advocates moving from the present signature legal pedagogy of the Socratic method to a manner of teaching that incorporates practical education with theoretical and doctrinal instruction and that emphasizes professional responsibility. The Report suggests that the most effective legal education occurs through three inter-related "apprenticeships"practical; cognitive or intellectual; and identity and purpose - which, experienced together, encourage students to explore all aspects of a legal problem and allow for contemporaneous feedback

Building on this recommendation, the Legal Information Conference attendees focused on defining a pedagogy of legal research instruction that recognizes the fundamental nature of legal research in legal education and law practice. The Statement expresses a comprehensive approach to legal research instruction that, when implemented, will significantly improve the preparation of law students for their legal careers.

\section{The Boulder Statement on Legal Research Education}

Legal research education teaches the resolution of legal problems through an iterative and analytical process. Students will experience a practical apprenticeship of identifying significant facts; determining legal issues and problems; and locating, evaluating, and manipulating research authorities.

Students will experience a cognitive apprenticeship by learning the importance of understanding the legal system in which their question arises and evaluating available legal resources. Through this apprenticeship the student will synthesize information about legal systems and resources to identify the best research plan for a given question. The students will also learn to continually re-evaluate their progress and results to arrive at the optimal answer to the legal problem.

Throughout the process, students will learn to apply the professional and ethical norms implicated by their research, which will reinforce their apprenticeship of identity and purpose. For legal research instruction, this includes an ongoing examination of professional standards including the identification of ethical responsibilities, the 
avoidance of plagiarism, and the fulfillment of the ethical duty to conduct adequate and thorough research.

Signed: June 22, 2009

Duncan Alford

University of South Carolina

Barbara Bintliff

University of Colorado

Paul D. Callister

University of Missouri-Kansas City

Stephanie Davidson

University of Illinois

Beth DiFelice

Arizona State University

Kumar R. Jayasuriya

Georgetown University

Thomas Kimbrough

Southern Methodist University

Anne Klinefelter

University of North Carolina

Judith Lihosit

University of San Diego

Robert Linz

University of Colorado
Susan Nevelow Mart

University of California, Hastings

Grace M. Mills

Hamline University

Alan Pannell

University of Colorado

Carol Parker

University of New Mexico

Robert C. Richards, Jr

Philadelphia, PA

Amanda Runyon

University of Texas

Sabrina Sondhi

Columbia University

Jane Thompson

University of Colorado

Sarah Valentine

City University of New York

Virginia Wise

Harvard University 


\section{Appendix B -- Boulder Statement on Legal Research Education: Signature Pedagogy Statement}

\section{Introduction}

The second Conference on Legal Information: Scholarship and Teaching brought together legal research professionals at the University of Colorado Law School in Boulder, Colorado on July 810, 2010. The purposes of the Conference were to continue to foster legal information scholarship and to resume work on the development of a signature pedagogy for legal research education, in accord with the 2009 Boulder Statement on Legal Research Education (available at http://www.colorado.edu/law/events/legalResearchEducation.pdf ). Participants at the 2010 Conference expanded upon the theoretical foundation of a signature pedagogy for legal research education, as expressed in the 2009 Boulder Statement, and now present this Signature Pedagogy Statement to define in more concrete terms the elements of a signature pedagogy.

Like the Boulder Statement on Legal Research Education, the Signature Pedagogy Statement is modeled on the analysis found in the Carnegie Foundation's EDUCATING LAWYERS: PREPARATION FOR THE PROFESSION OF LAW (2007), generally referred to as the "Carnegie Report." The Signature Pedagogy Statement reflects, in particular, the application to legal research education of the characteristics identified for "Legal Education's Signature Pedagogy" as described in the Carnegie Report (pp. 50-59). Conference attendees found the Signature Pedagogy Statement to be an important and necessary step forward in the reformation of legal research instruction to better serve student needs and the realities of legal practice.

Using the Carnegie Report's analysis of a signature pedagogy, attendees at the Conference on Legal Information described the surface structure, deep structure, tacit structure, and shadow structure of a signature pedagogy of legal research education. The Carnegie report defines the surface structure as the features and behaviors of a pedagogy that are readily apparent. The deep structure comprises the underlying theories or models behind the surface structure. The tacit structure refers to the values modeled by the surface structure. The shadow structure is that which is missing or the values that are not engaged through the pedagogy. The four structures together describe the pedagogy.

\section{The Boulder Statement on Legal Research Education: Signature Pedagogy Statement} expresses an ideal pedagogy for legal research educators in the U.S. but does not prescribe specific teaching methods; those are described in other literatures. The Signature Pedagogy Statement is offered in the spirit of the ongoing process of improving the preparation of law students for their legal careers. Work in future Boulder Conferences will focus on implementation strategies for the Boulder Statement on Legal Research Education and the Signature Pedagogy Statement. 


\section{The Boulder Statement on Legal Research Education: Signature Pedagogy Statement}

\section{Surface Structure}

We teach an intellectual process for the application of methods for legal research by:

1) Using a range of teaching methodologies and a mix of realistic problem types;

2) Showing the relationship of legal structure to legal tools and evaluating the appropriate use of those tools;

3) Inculcating the practice of iterative research strategies; and

4) Providing regular assessment.

\section{Deep Structure}

The surface structure above enables students to master analytic and metacognitive approaches to:

1) Find and evaluate sources in the context of the legal questions;

2) Determine legal context, access authority, and understand how what is found relates to the legal question; and

3) Synthesize knowledge of the legal resources and institutional structures to implement research design, and evaluate and communicate the results.

\section{Tacit Structure}

The surface structure models values, attitudes and norms of ethical professional behavior, including:

1) Professional duties, both while representing clients and researching for other purposes, which consist of but but are not limited to accountability, honesty, thoroughness, cost- and timeeffectiveness, and balancing competing duties; and

2) Professional development, which incorporates but is not limited to critical self-assessment and critical strategic thinking, self-directed lifelong learning, problem solving, and the management of uncertainty and ambiguity within the research process.

\section{Shadow Structure}

The surface structure can be limited because:

1) The curriculum often does not recognize legal research as a necessary, intellectual skill;

2) Legal research instruction is not appropriately integrated within the curriculum;

3) The academy often undervalues librarians as research experts and underutilizes them as research faculty; and

4) The legal education environment is necessarily a simulation, and is limited in its ability to provide a holistic context for client contact. 


\section{Attendees:}

Duncan Alford, University of South Carolina

Leta Ambrose, University of Denver

David Armond, Brigham Young University

Barbara Bintliff, University of Texas

Margaret Butler, Georgia State University

Paul Callister, UMKC

Matthew Cordon, Baylor University

Stephanie Davidson, University of Illinois

Kerry Fitz-Gerald, Seattle University

Kumar Jayasuriya, Georgetown University

Nancy Johnson, Georgia State University

Dennis Kim-Prieto, Rutgers

Jootaek Lee, University of Miami

Robert Linz, University of Colorado

Susan Nevelow-Mart, Hastings Law School

Shawn Nevers, Brigham Young University

Alan Pannell, University of Colorado

Carol Parker, University of New Mexico

Phebe Poydras, Florida A\&M University

Amanda Runyon, University of Texas

Leslie Street, University of North Carolina

Jane Thompson, University of Colorado

Sarah Valentine, CUNY

Jennifer Wertkin, Columbia University 